\title{
SPACE-TIME VARIABILITY OF THE RONCADOR RIVER BASIN IN THE CHANGE OF LAND USE AND COVER AND ITS CORRELATION WITH CLIMATIC VARIABLES
}

\author{
VARIABILIDADE ESPAÇO-TEMPORAL DA BACIA HIDROGRÁFICA DO RIO \\ RONCADOR NA MUDANÇA DO USO E COBERTURA DO SOLO E SUA \\ CORRELAÇÃO COM VARIÁVEIS CLIMÁTICAS
}

\author{
Raquel de Oliveira SANTOS${ }^{1}$; Rafael Coll DELGADO' ${ }^{1}$ Marcos Gervasio PEREIRA²; \\ Leonardo Paula de SOUZA ${ }^{3}$; Paulo Eduardo TEDORO ${ }^{4}$; Carlos Antonio da Silva JUNIOR ${ }^{5}$; \\ Giovani Glaucio de Oliveira COSTA ${ }^{6}$ \\ 1. Universidade Federal Rural do Rio de Janeiro, Instituto de Florestas, Departamento de Ciências Ambientais, \\ rafaelcolldelgado32@gmail.com; 2. Universidade Federal Rural do Rio de Janeiro, Departamento de Solos, \\ mgervasiopereira01@gmail.com; 3. Universidade Federal do Acre, Centro de Ciências Biológicas e da Natureza, \\ leonardo.acre@gmail.com; 4. Universidade Federal do Mato Grosso do Sul, Departamento de Ciências Agrárias, \\ pauloeduardoteodoro@gmail.com; 5. Universidade do Estado do Mato Grosso, Departamento de Geografia, \\ carlosjr@unemat.br; 6. Universidade Federal Rural do Rio de Janeiro, Instituto Multidisciplinar, \\ giovaniglaucio@hotmail.com.
}

\begin{abstract}
The objective of this study was to evaluate the space-time dynamics of the soil use and occupation of the Rio Roncador river basin between 1985 and 2010. The scenes were classified by two methods (partially unsupervised - K-Means and supervised - Maximum likelihood), the Thematic Mapper sensor products on the LANDSAT 5 orbital platform were used for both images of a 25-year time series (1985 to 2000). In order to measure the accuracy of the field the computer application Google Earth was used, in which nine classes (urban area, agricultural area, pasture, exposed soil, native forest, secondary vegetation, mangrove, altitude field and water) were collected. A multiple linear regression was performed, correlating the Normalized Difference Vegetation Index - mean NDVI (dependent variable) with the independent climatic variables (global solar radiation - $\mathrm{MJm}^{-2} \mathrm{day}^{-1}$, average air temperature $-{ }^{\circ} \mathrm{C}$, relative humidity $-\%$, evapotranspiration - $\mathrm{mm} \mathrm{d}^{-1}$, and rain - mm). According to the general classification by Kappa parameter of the images for 2005 and 2010, they were identified as very good (68\% and $74 \%)$. These results confirm that the Roncador River Basin is undergoing transformation in its landscape, with an average reduction of $-49 \%$ in native vegetation areas due to the increase in urban areas (25\%) and agriculture (31\%). The statistical analysis showed that rainfall and air temperature were the only variables that presented significant sigma (0.04) and (0.02). The obtained coefficient of determination indicated that $47 \%$ of the variations of the "vegetation index" are explained by the environmental variables.
\end{abstract}

KEYWORDS: Landscape change. Water availability. Environmental disasters. Image processing.

\section{INTRODUCTION}

The human perception has been changing the conservation of natural resources, which may jeopardize the future generations. An example of the anthropic modifications and the reduction of the Atlantic Forest Biome that now owns only $7 \%$ of the original (MMA, 2016). The Atlantic Forest has been subjected to numerous changes in its ecosystem, being the land use and occupation the main causes of these transformations. Even today, impacts promoted by anthropic actions that can compromise their original preservation are verified (GASPARINI et al., 2013; SANTANA et al., 2016).

The change in the vegetation cover of the Atlantic Forest is a result of great impact activities on it, such as removal of permanent preservation areas in the vicinity of the basins (COUTINHO et al., 2013) and increase of urban areas without planning. The generation of negative impacts due to inappropriate management of land use and vegetation cover in basins can lead to climate change, which is directly correlated with environmental disasters (COUTINHO et al., 2013). Many authors have used several techniques for mapping the detection of changes in land use and occupation in basins (SILVA et al., 2014; RIBEIRO et al., 2016; BRASILEIRO et al., 2016; ALVES RÊGO et al., 2012). The study of the vegetation allows to generate information on the nature of the territory, also serving as a tool for the territorial planning of basins to mitigate the environmental 
impacts caused by the climatic changes caused by the intensification of anthropic actions (FREITAS et al., 2012 e IPCC, 2015,).

In addition to providing information on vegetation dynamics, geotechnology tools have been used mainly to understand the spectral pattern of vegetation indexes associated with climatic factors, such as rainfall, air temperature, among others (DELGADO et al., 2012; GOULART et al., 2015; NUNES et al., 2015). The reduction of biodiversity due to anthropic factors, followed by large episodes of forest fires, fires and extreme droughts, has a devastating impact on forest systems on a regional and global scale (CAÚLA et al., 2015). In this sense, the objective of this work was to evaluate the spatial-temporal evolution of the different classes of the land use and its relationship with the climate, in the Roncador River Basin in Magé, RJ.

\section{MATERIAL AND METHODS}

\section{Study area}

Twenty five images of the TM (Thematic Mapper) sensor of Landsat-5 satellite (Figure 1) were selected, orbit 217 and point 76 of the historical series available in the Catalog of Images on the site of the National Institute for Space Research (INPE, 2019) in order to obtain concomitantly images with lower cloud cover. In addition to the careful choice of very low cloud cover, TM images of Landsat 5 are mostly dry (April to September) (Figure 1).

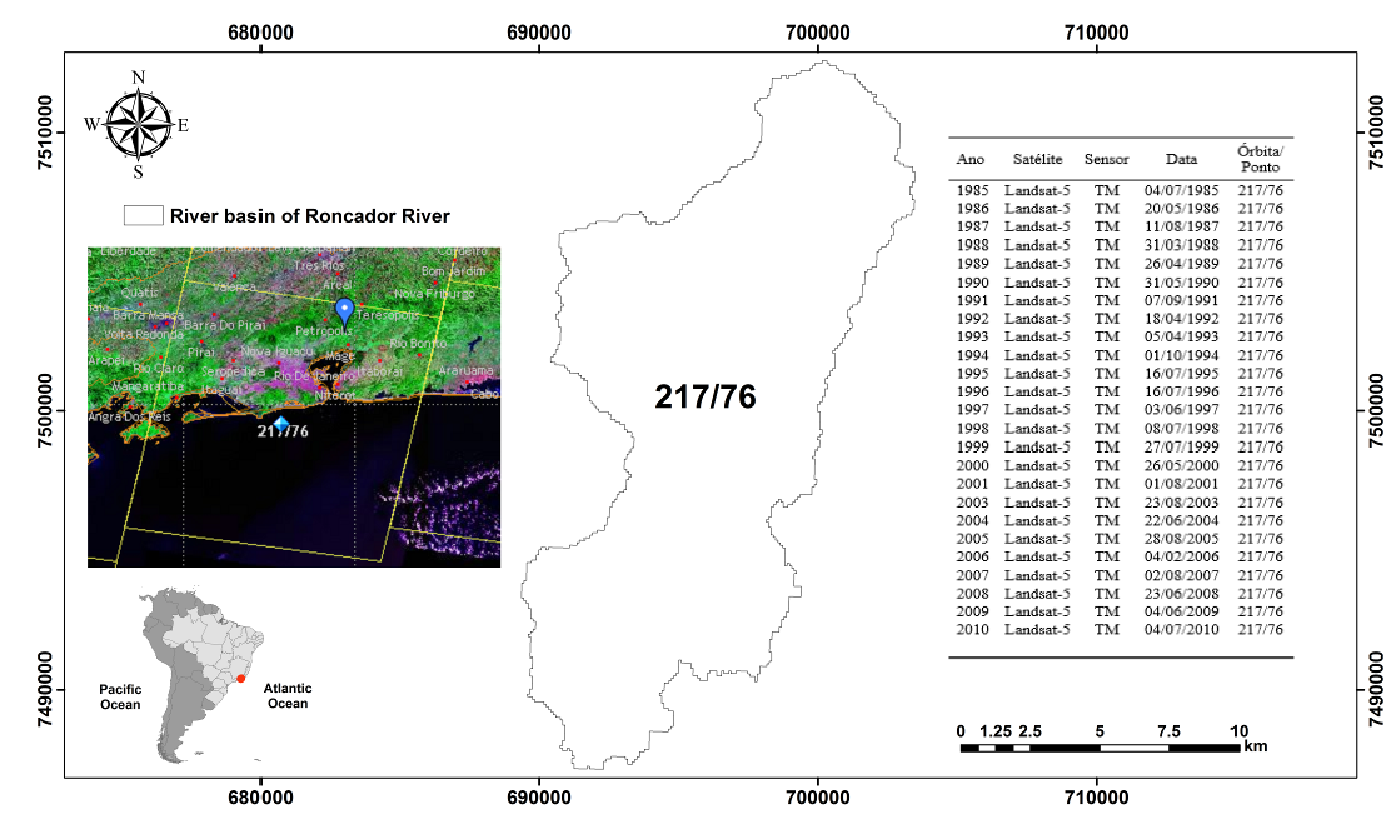

Figure 1. Geographic location of the orbit and point, and time series used by Thematic Mapper sensor for the Roncador River Basin.

\section{Processing of Thematic Mapper Image}

The images were processed in ERDAS IMAGINE 2015 software, using the Model Maker platform. The SEBAL (Surface Energy Balance Algorithm for Land) proposed by Bastiaanssen et al. (1998) and Allen et al. (2002) was used as standard. In the software, the union of the satellite bands, the radiometric calibration, the reflectivity and the NDVI (Normalized Difference Vegetation Index) were calculated. The ArcGIS software - version 10.2 was used for the creation of vector data, database and thematic maps.

For the calculation of the spectral radiance of each band $\left(\mathrm{L}_{\lambda \mathrm{i}}\right)$, where the Digital Number (ND) of each image pixel is converted into monochromatic spectral radiance, representing the solar energy reflected by each pixel, per area, time, solid angle and wavelength unit measured at the Landsat 5 satellite level (approximately $705 \mathrm{~km}$ high) for bands 1, 2, 3, 4, 5, and 7; For band 6, this radiance represents the energy emitted by each pixel and can be obtained by the equation proposed by Markham and Baker (1987):

$\mathrm{L}_{\lambda \mathrm{i}}=a_{i}+\frac{b_{i}-a_{i}}{255} \times N D$

In which: $\mathrm{L} \lambda \mathrm{i}=$ spectral radiance of each band $\left(\mathrm{Wm}^{-2} \mathrm{sr}^{-1} \mu \mathrm{m}^{-1}\right) ; \mathrm{a}$ and $\mathrm{b}=$ are the minimum and maximum spectral radiances obtained in the paper by Chander et al. (2009) $\left(\mathrm{Wm}^{-2} \mathrm{sr}^{-1} \mu \mathrm{m}^{-1}\right)$; ND $=$ pixel intensity (digital number - integer 0 to 255); 
$\mathrm{i}=$ are the bands $(1,2,3,4,5,6$ and 7$)$ of the Landsat-5 satellite.

The monochromatic reflectance of each band $\left(\rho_{\lambda_{\mathrm{i}}}\right)$, defined as the ratio between the solar radiation flux reflected by the surface and the incident solar radiation flux was obtained according to the equation (BASTIAANSSEN et al., 1998; ALLEN et al., 2002):

$\rho_{\lambda i}=\frac{\pi \cdot L_{\lambda i}}{E_{\lambda i} \cdot \cos Z \cdot d_{r}}$

In which: $\rho_{\lambda_{\mathrm{i}}}=$ monochromatic reflectance; $\mathrm{L}_{\lambda \mathrm{i}}=$ spectral radiance of each band $\left(W m^{-2} \mathrm{sr}^{-1} \mu \mathrm{m}^{-1}\right)$; $E_{\lambda i}=$ spectral solar irradiance of each band at the top of the atmosphere $\left(W^{-2} \mu \mathrm{m}^{-1}\right)$ information in the paper by Chander et al. (2009); $\mathrm{Z}=$ solar zenith angle (obtained in the header of the images acquired, and it depends on the orbit, point and time of the year); $\mathrm{dr}=$ astronomical day of the year (U.A), according to Inverse of the square of the relative distance Earth-Sun given by Iqbal (1983); i $=$ are the bands $(1,2,3,4,5$ and 7$)$ of the TM Landsat- 5 satellite. For each image, the union of the reflectivity was performed with the Layer Stack tool of ERDAS IMAGINE 2015 software, with the exception of band 6 , because it is a non-reflective thermal band.

Normalized Difference Vegetation Index (NDVI) was obtained by means of the ratio between the near infrared $(\rho \mathrm{IV})$ and red $(\rho \mathrm{V})$ reflectivities and their sum, was obtained according to the equation (ROUSE et al.,1973):

$$
\mathrm{NDVI}=\frac{\rho_{\mathrm{IV}}-\rho_{\mathrm{V}}}{\rho_{\mathrm{IV}}+\rho_{\mathrm{V}}}
$$

In which: Near infrared $\left(\rho_{\mathrm{IV}}\right)$ and; Red band

\section{Elaboration of Mapping}

Because the river basin region lies in an area with great altimetric amplitude (the hilltops cause the shading of the image, mistaking the partially unsupervised K-means algorithm). The K-Means algorithm was used for the six images of the studied scenarios, the shadows of the mountains caused a confusion in the algorithm, classifying the shaded regions as urban area, not being able to choose this classification, since the basin region of greatest altitude is surrounded by Montana Forest, and it is inside the park of Serra dos Órgãos (MMA, 2017).

When this situation was verified, the supervised classification was carried out, which ensured a better accuracy for the studied images, however, the difficulty of access in some points of the basin region and the good resolution of images from Google Earth only for 9/29/2005 the supervised classification for all scenes cannot be employed. This pattern justifies the choice to perform the supervised classification for the scenario (2005 and 2010), as it shows a greater wealth of detail and less confusion between the different classes of land use and cover, when using the maximum likelihood algorithm, which allowed the best representative for the location, to the other dates (1985 to 2000) the use of the non-supervised method (FREITAS et al., 2012) was adequate.

The first stage of the work consisted in the collection of samples from high resolution 2.5 meters images of SPOT (Google Earth), referring to the classes of study in the Roncador River basin located in Magé, RJ such as: (secondary vegetation, mangrove, field altitude, primary forest, urban area, agricultural area, exposed soil, degraded pasture and water) (Table 1). $\left(\rho_{\mathrm{V}}\right)$.

Table 1. Classes and number of samples defined for classification.

\begin{tabular}{lll}
\hline Class & Number of samples & Description \\
\hline Urban area & 50 & Area included urban perimeter \\
Exposed Soil & 50 & Area exposed by Grazing and ground road \\
Agricultural Area & 50 & Annual coconut / banana / corn crops \\
Pasture & 50 & Gramineae \\
Primary forest & 50 & Native vegetation in Clímax state \\
Secondary forest & 50 & Secondary Vegetation \\
Altitude Field & 50 & Region of discovered rocks \\
Mangrove & 50 & Typical Vegetation of arboreal Mangrove \\
Water & 50 & Water body \\
\hline
\end{tabular}

\section{Meteorological data and vegetation}

Evaluating meteorological data is essential for the estimation of environmental impacts on ecosystems (XAVIER et al., 2016), therefore this study aimed to analyze the possible influences the meteorological variables (average air temperature, global solar radiation, rain, relative humidity and 
evapotranspiration) may be caused by the landscape dynamics in the Roncador river basin.

Daily climatic data were obtained for the same time period of images from Thematic Mapper (1985 to 2010) from the following site: http://careyking.com/data-downloads/, which contains a series of $1980-2013$ for Brazil with good spatial resolution $\left(0,25^{\circ} \times 0,25^{\circ}\right)$.

The files are in the (NetCDF) format, the database was made available by Xavier et al. (2016), which interpolated the climatic data for the whole Brazil. The information in their studies was collected from the National Institute of Meteorology (INMET), National Water Agency (ANA) and the Department of Water and Electric Power of São Paulo. The time series of NDVI images encompasses the same 25-year period. The procedure for generating the time series was performed in ArcGis 10.2 software, which allows the visualization through histograms of the mean values of the NDVI images.

\section{Statistical analysis}

A general multiple regression model was calculated from the "Enter" method, where all variables are entered at the same time and an $\mathrm{R}^{2}$ is reported for the quality of the model generated. The regression analysis was estimated through $\mathrm{R}^{2}$ and the weights of the coefficients, determining the linear relationships between the set of explanatory variables and the response variable. Thus, the tests performed in the multiple regression to determine which variables influence the dynamics of the basin landscape were the following: Test for significance of the multiple linear regression, Test for significance of regression parameter, Shapiro-Wilk homogeneity test, Durbin-Watson test, multicollinearity test. The multicolinarity test analyzes the linear relationship between the independent variables. This relationship was evaluated through the variance inflation factor (VIF).

\section{RESULTS AND DISCUSSION}

From the unsupervised classification through TM sensor images and subsequent quantification of soil cover classes in the study area (Table 2 and Figure 2), it was found that for 1985 there were 12147.03 ha of native vegetation cover and in 2010 the same class presented the value 7247.61 ha. Therefore, in the period of 25 years, there was an average reduction of $49 \%$ of the native vegetation cover in the area of the river basin, indicating an average annual reduction of around $2.36 \%$ over the 25 years. This reduction of plant cover represented significant growth in urban and agricultural areas of $31 \%$ and $25 \%$. The permanent preservation areas of altitude and mangrove fields also showed reductions of $9.5 \%$ and $10 \%$, respectively. The pasture class also decreased by $1.6 \%$. The areas classified as exposed soil presented increase, but with values lower than $1 \%$.

Table 2. Statistics of land use and land cover from 1985 to 2010.

\begin{tabular}{llllllll}
\hline Classes & $\mathbf{1 9 8 5}$ & $\mathbf{1 9 9 0}$ & $\mathbf{1 9 9 5}$ & $\mathbf{2 0 0 0}$ & $\mathbf{2 0 0 5}$ & $\mathbf{2 0 1 0}$ & Difference \\
\hline Mangrove & $1,261.35$ & 394.11 & $1,483.47$ & 568.26 & 373.50 & 190.53 & $-10.71 \%$ \\
Altitude field & $1,579.32$ & 326.25 & $1,024.02$ & 623.43 & $1,252.35$ & 625.86 & $-9.53 \%$ \\
Secondary & $2,335.77$ & $2,384.55$ & $3,052.26$ & $2,348.19$ & $2,310.03$ & $3,538.89$ & $12.03 \%$ \\
Vegetation & & & & & & & \\
Primary forest & $12,147.03$ & $11,986.02$ & $10,397.52$ & $9,350.01$ & $9,129.96$ & $7,247.61$ & $-48.99 \%$ \\
Agricultural area & 6.21 & 937.08 & 633.24 & 576.27 & $1,154.43$ & $3,071.7$ & $31.00 \%$ \\
Pasture & 20.52 & 0.45 & 5.85 & $1,235.61$ & 609.30 & 182.25 & $1.62 \%$ \\
Exposed soil & 23.76 & 0.27 & 420.93 & 631.62 & 899.37 & 45.54 & $0.22 \%$ \\
Urban area & $1,125.54$ & 557.64 & $1,514.79$ & $3,046.23$ & $2,796.75$ & $3,649.32$ & $25.00 \%$ \\
Water & 116.10 & $2,029.23$ & 83.52 & 235.98 & 89.91 & 63.9 & $-0.52 \%$ \\
Total & $18,615.60$ & $18,615.60$ & $18,615.60$ & $18,615.60$ & $18,615.60$ & $18,615.60$ & \\
\hline
\end{tabular}

In a study carried out in São Paulo in the implementation of the trench in Guarulhos, Moledo et al. (2015) also highlighted the importance of vegetation in maintaining the balance of the Tanque Grande basin, where the increasing urbanization in the metropolitan region of São Paulo contributes to the suppression of native vegetation, soil degradation and even the increase in air pollution. In the evaluation of environmental impacts in the Estiva stream in Betim, Minas Gerais, Soares et al. (2016) observed that the most significant environmental impacts that contributed to the deterioration of the environmental quality of the area were: degradation and/or removal of riparian forest, dumping of domestic sewage, irregular 
housing, inadequate disposal of solid waste, fires and other.

The landscape transformation and recurrent environmental impacts in the hydrographic unit of this study are directly related to the inappropriate anthropic use in the vicinity of the river basin, in which it can be visualized in the land use and occupation scenarios of the years 1985, 1990, 1995 and 2000 (Figure 2).

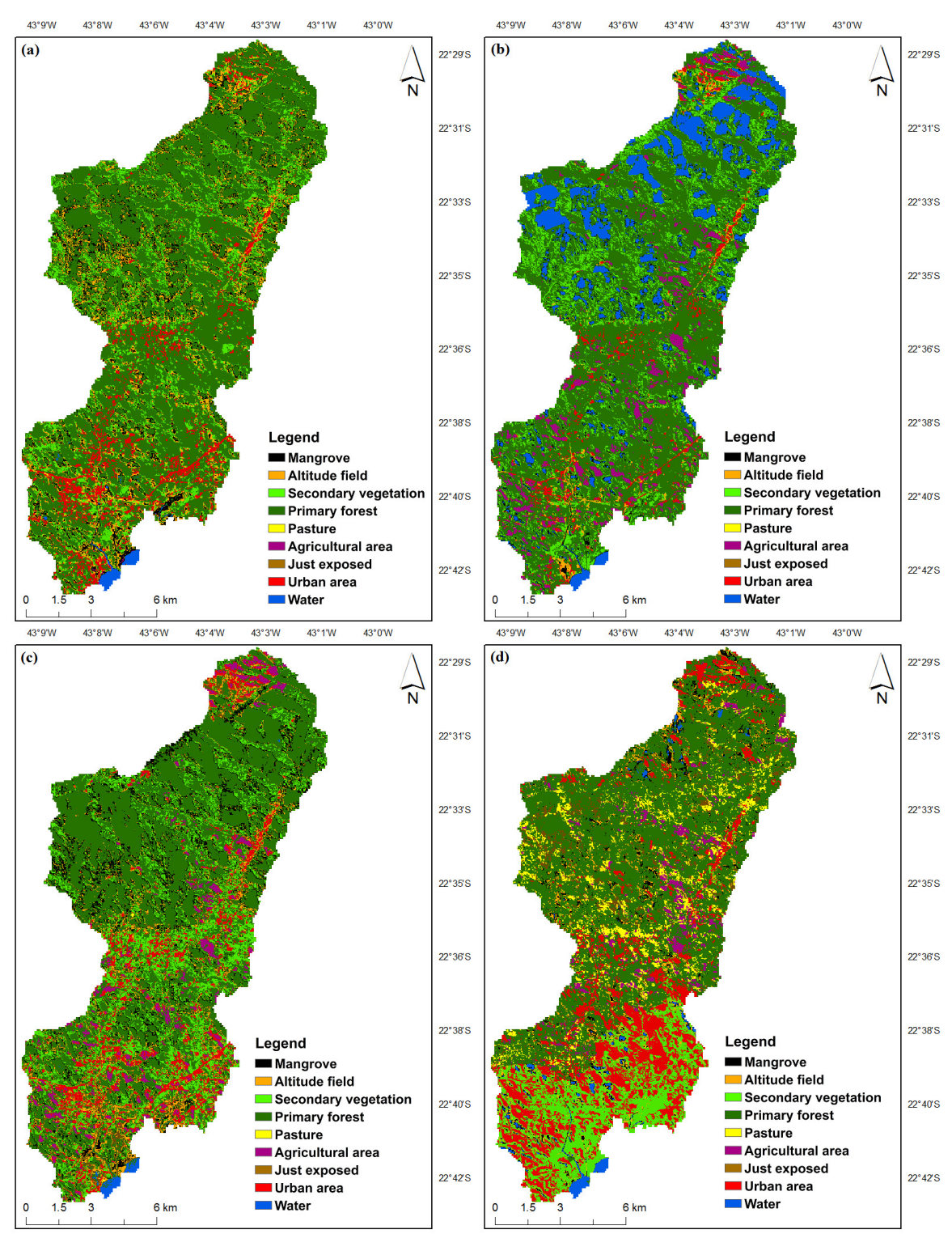

Figure 2. Classes of land use and occupation for the years 1985 (a), 1990 (b), 1995 (c) and 2000 (d) by the KMeans method in the Roncador River basin.

Tables 3 and 4 show the results of the error matrix of the image classified by the maximum likelihood method (supervised classification). The pasture and soil class for 2005 presented the lowest error matrix of $44 \%$ and $33 \%$, respectively (Table 3). In 2010, the agricultural area class was the lowest error $50 \%$ (Table 4). These results show that the year 2010 presented the best overall accuracy of $77 \%$, while in 2005 the value was only $68 \%$.

The Kappa index (Table 5) estimated for the classified image by using the maximum likelihood algorithm presented a 63\% accuracy for 2005 and
$74 \%$ for 2010 , being classified as very good, according to the criteria proposed by Landis and Kock et al. (1977). The Kappa index, when observed by class for 2005, presented low values for areas of exposed soil and altitude field (20\% and $21.88 \%$ ). The found may be associated to the predominance of granitic and migmatitic rocks. Additionally, the rugged terrain originates shallow soils and forms a mosaic of microhabitats (MOCOCHINSK and SCHEER, 2008). The classes of urban and mangrove areas (53\% and 48\%). The forest class presented representative values 
according to the Kappa index (76\% and $79 \%)$. However, the classes of pasture and water showed excellent value according to the Kappa index $(100 \%$ and $100 \%)$.

Table 3. Matrix of errors of the Landsat-5 image year 2005 classified by the maximum likelihood algorithm.

\begin{tabular}{llllll}
\hline Classes & Total Reference & $\begin{array}{l}\text { Total } \\
\text { Classification }\end{array}$ & $\begin{array}{l}\text { Correct } \\
\text { Number }\end{array}$ & $\begin{array}{l}\text { Precision } \\
\text { Producer }\end{array}$ & $\begin{array}{l}\text { User } \\
\text { Accuracy }\end{array}$ \\
\hline $\begin{array}{l}\text { Primary Forest } \\
\text { Secondary }\end{array}$ & 12 & 11 & 9 & $75.00 \%$ & $81.82 \%$ \\
$\begin{array}{l}\text { Vegetation } \\
\text { Mangrove }\end{array}$ & 2 & 6 & 5 & $55.56 \%$ & $83.33 \%$ \\
Altitude Field & 2 & 4 & & & \\
Pasture & 9 & 4 & 2 & $100 \%$ & $50.00 \%$ \\
Agricultural area & 2 & 4 & 1 & $50.00 \%$ & $25.00 \%$ \\
Exposed soil & 3 & 4 & 4 & $44.44 \%$ & $100 \%$ \\
Urban area & 5 & 4 & 2 & $100 \%$ & $50.00 \%$ \\
Water & 6 & 7 & 1 & $33.33 \%$ & $25.00 \%$ \\
Total & 50 & 6 & 4 & $80.00 \%$ & $57.14 \%$ \\
\hline
\end{tabular}

General Accuracy of Classification: $=68 \%$

Table 4. Matrix of errors of the Landsat-5 image year 2010 classified by the maximum likelihood algorithm.

\begin{tabular}{llllll}
\hline Classes & Total Reference & $\begin{array}{l}\text { Total } \\
\text { Classification }\end{array}$ & $\begin{array}{l}\text { Correct } \\
\text { Number }\end{array}$ & $\begin{array}{l}\text { Precision } \\
\text { Producer }\end{array}$ & $\begin{array}{l}\text { User } \\
\text { Accuracy }\end{array}$ \\
\hline Primary Forest & 8 & 8 & 8 & $100 \%$ & $100 \%$ \\
Secondary Vegetation & 9 & 6 & 5 & $55.56 \%$ & $83.33 \%$ \\
Mangrove & 7 & 5 & 5 & $71.43 \%$ & $100 \%$ \\
Altitude Field & 6 & 5 & 5 & $83.33 \%$ & $100 \%$ \\
Pasture & 2 & 4 & 2 & $100 \%$ & $50.00 \%$ \\
Agricultural area & 6 & 6 & 3 & $50.00 \%$ & $50 \%$ \\
Exposed soil & 2 & 2 & 2 & $100 \%$ & $100 \%$ \\
Urban area & 2 & 7 & 2 & $100 \%$ & $28.57 \%$ \\
Water & 6 & 5 & 5 & $83.33 \%$ & $100 \%$ \\
Total & 48 & 48 & 37 & & \\
\hline
\end{tabular}

General Accuracy of Classification: $77.00 \%$

Table 5: Results of the Kappa index of the Landsat-5 image classified by the maximum likelihood algorithm.

\begin{tabular}{lll}
\hline Classes Classes & $\begin{array}{l}\text { Kappa } \\
\mathbf{2 0 0 5}\end{array}$ & $\begin{array}{l}\text { Kappa } \\
\mathbf{2 0 1 0}\end{array}$ \\
\hline Primary Forest & 0.76 & 1.00 \\
Secondary Vegetation & 0.80 & 0.79 \\
Mangrove & 0.48 & 1.00 \\
Altitude Field & 0.22 & 1.00 \\
Pasture & 1.00 & 0.48 \\
Agricultural area & 0.48 & 0.43 \\
Exposed soil & 0.20 & 1.00 \\
Urban area & 0.52 & 0.25 \\
Water & 1.00 & 1.00 \\
Kappa Global & $\mathbf{0 . 6 3}$ & $\mathbf{0 . 7 4}$ \\
\hline
\end{tabular}

For 2010, low values were verified for urban area $(25 \%)$, classes of agricultural and pasture (48\% and $43 \%)$, representative value forest $(100 \%$ and $79 \%)$. However, the classes of exposed soil, water, mangrove and altitude field presented excellent values, $100 \%$. Comparing the two scenes (2005 and 2010), it can be observed that the classifications of the features by the algorithm vary 
widely from one year to another for the classes of exposed soil, altitude field, pasture and agricultural area (Table 5 and Figure 3). However, a good standard for forest classification remains.

Similar results were found by Brasileiro et al. (2016), when studying the efficiency of the maximum likelihood classifier for mapping of land use and land cover in Quixeramobim, Ceará, the algorithm was more efficient in the vegetation classification of caatinga in relation to other features like pasture and exposed soil that presented low spectral responses.
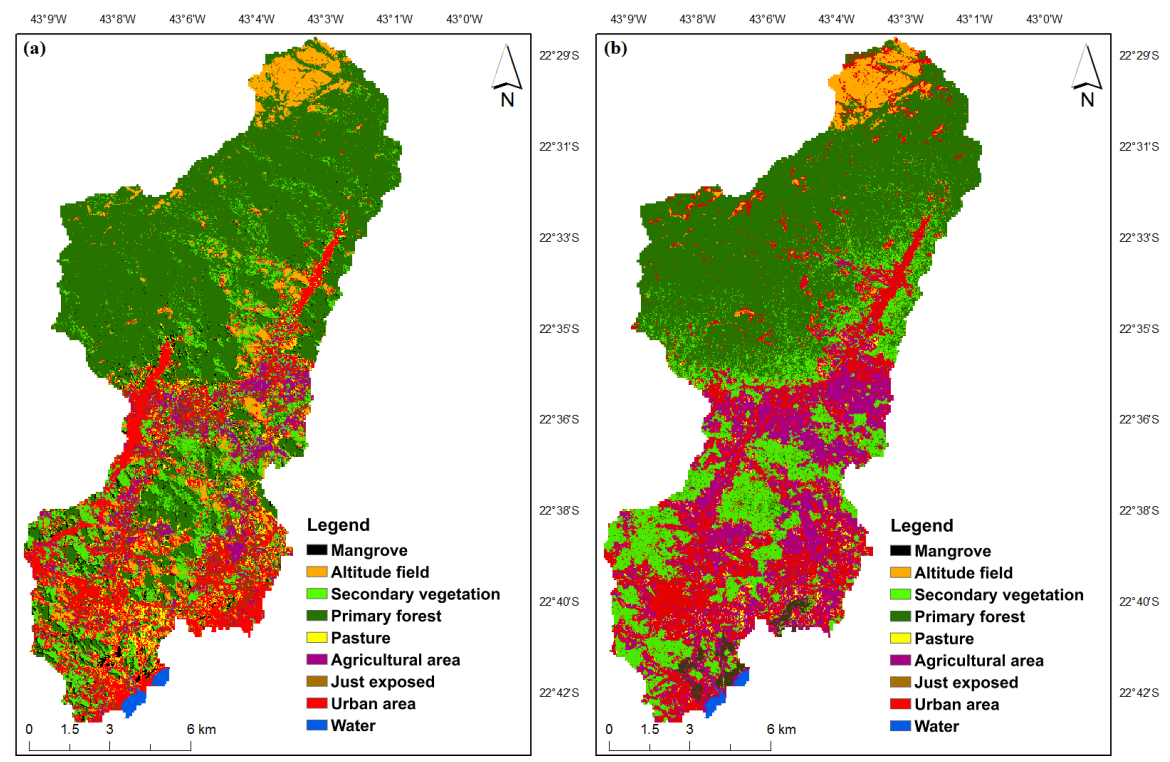

Figure 3. Classes of land use and coverage for 2005 (a) and 2010 (b) by the maximum likelihood method in the Roncardor River basin.

In the statistical analysis between the environmental variables and the NDVI vegetation index, the ANOVA test presented a p-value of 0.029 , which indicates that the variable "NDVI" is influenced by the variables included in the model. The value obtained from $\mathrm{R}^{2}$ was 0.47 , that is, $47 \%$ of the variations of the "vegetation index" are explained by the environmental variables. Among the studied variables, it was found that the coefficients that presented the greatest significance in the equations were rainfall with growth of 0.023 and air temperature with decrease of 0.008 , the other variables did not significantly influence NDVI.

In a temporal study with images from Thematic Mapper in the city of Rio de Janeiro, NDVI in $60 \%$ of the years was the index that presented the highest correlation with rainfall compared to other vegetation indexes (GOULART et al., 2015). Other authors also detected growth of covers such as: agricultural crops, natural forest and caatinga, associating the increase of tree cover with rainfall and vegetation indexes (DELGADO et al., 2012; FRANCISCO et al., 2015).

\section{CONCLUSIONS}

The Roncador River Basin is undergoing transformation in its landscape, with an average reduction of $(-49 \%)$ in native vegetation areas due to an increase in urban areas $(25 \%)$ and agriculture $(31 \%)$.

The vegetation classes found in this ecosystem, mainly in protected areas, are being replaced by Pasture formations, agriculture, urban area, as a result of anthropic activities.

RESUMO: O objetivo deste estudo foi de analisar espaço-temporalmente a dinâmica do uso e ocupação do solo da bacia hidrográfica do Rio Roncador, localizada no município de Magé no Estado do Rio de Janeiro, entre os anos de 1985 a 2010. As cenas foram classificadas por dois métodos (parcialmente nãosupervisionada - K-Means e supervisionada - Máxima Verossimilhança), para ambos foram utilizados os produtos abordo da plataforma orbital LANDSAT 5 do sensor Thematic Mapper, para as imagens de uma sérietemporal de 25 anos (1985 a 2000). Para a aferição como verdade de campo utilizou-se se o aplicativo computacional Google Earth, no qual foram coletadas nove classes (área urbana, área agrícola, pastagem, solo exposto, floresta nativa, vegetação secundária, manguezal, campo de altitude e água). Foi feita uma regressão 
linear múltipla, correlacionando o Índice de Vegetação da Diferença Normalizada - NDVI médio (variável dependente) com as variáveis climáticas independentes (radiação solar global - $\mathrm{MJm}^{-2} \mathrm{dia}^{-1}$, temperatura média do ar $-{ }^{\circ} \mathrm{C}$, umidade relativa do ar $-\%$, evapotranspiração $-\mathrm{mm} \mathrm{d}^{-1}$, e chuva $-\mathrm{mm}$ ). Segundo a classificação geral pelo parâmetro Kappa das imagens para os anos de 2005 e 2010 estas foram identificadas como muito bom (68\% e 74\%). Estes resultados comprovam que a Bacia Hidrográfica do Rio Roncador está passando por transformação em sua paisagem, com redução média de $(-49 \%)$ das áreas de vegetação nativa por aumento de áreas como urbana (25\%) e agricultura (31\%). A análise estatística evidenciou que a variável climática chuva e temperatura do ar foram às únicas que apresentaram sigma significativo (0.04) e (0.02), a regressão múltipla com $\mathrm{R}^{2}$ de 0.47 , que significa que $47 \%$ das variações do "índice de vegetação" são explicados pelas variáveis ambientais.

PALAVRAS-CHAVE: Landscape change. Water availability. Environmental disasters. Image processing.

\section{REFERENCES}

ALLEN, R.; TASUMI, M.; TREZZA, R. SEBAL (Surface Energy Balance Algorithm for Land) - Advanced Training and Users Manual - Idaho Implementation, version 1.0, Idaho University, 2002.

ALVES RÊGO, S. C.; SOUZA DE LIMA, P. P.; SILVA LIMA, M. N.; RODRIGUES MONTEIRO, T. R. Análise comparativa dos índices de vegetação NDVI e SAVI no município de São Domingos do Cariri-PB. Revista Geonorte, Amazonas, v. 2, n. 4, p. 1217-1229, 2012.

BASTIAANSSEN, W. G. M.; MENENTI, M.; FEDDES, R. A.; HOLTSLAG, A. A. M. The surface energy balance algorithm for land (SEBAL): Part 1 formulation, Journal of Hydrology, v. 212-213, p.198-212, 1998. https://doi.org/10.1016/S0022-1694(98)00253-4

BRASILEIRO, F. G.; OLIVEIRA, C. M. M.; RODRIGUES, R. A.; DELGADO, R. C. Classificação de Imagem orbital pelo método de Máxima Verossimilhança em Quixeramobim, Ceará, Brasil. Revista Geográfica Acadêmica, Boa Vista, v. 10, n. 1, p. 81-92, 2016. http://dx.doi.org/10.18227/16787226rga.v10i1.3549

CAÚlA, R. H.; OLIVEIRA-JÚNIOR, J. F.; LYRA, G. B.; DELGADO, R. C.; HEILBRON FILHO, P. F. L. Overview of fire foci causes and locations in Brazil based on meteorological satellite data from 1998 to 2011. Environmental Earth Sciences, v. 74, n.2, p. 1497-1508, 2015. DOI 10.1007/s12665-015-4142-z

CHANDER, G.; MARKHAM, B.; HELDER, D. Summary of current radiometric calibration coefficients for Landsat MSS, TM, ETM+ and EO-1 ALI sensors. Remote Sensing of Environment, v.113, p.893-903, 2009. https://doi.org/10.1016/j.rse.2009.01.007

COUTINHO, M. P. O Código Florestal Atual (Lei Federal n 12.651/2012) e suas implicações na prevenção de desastres naturais. Sustentabilidade em Debate, v. 4, n.2, p. 237-256, 2013.

DELGADO, R. C.; SEDIYAMA, G. C.; COSTA, M. H.; SOARES, V. P.; ANDRADE, R. G. Classificação espectral de área plantada com a cultura da cana-de-açúcar por meio da árvore de decisão. Revista Engenharia Agrícola, Jaboticabal, v. 32, n. 2, p. 369-380, 2012. http://dx.doi.org/10.1590/S0100-69162012000200017

FRANCISCO, P. R. M.; BRITO CHAVES, I.; CHAVES, L. H. G.; de LIMA, E. R. V.; da SILVA, B. B. Análise espectral e avaliação de índices de vegetação para o mapeamento da caatinga. Revista Verde de Agroecologia e Desenvolvimento Sustentável, Pombal, v. 10, n. 3, p. 01-12, 2015.

http://dx.doi.org/10.18378/rvads.v10i3.3046 
FREITAS, D. M.; DELGADO, R. C.; ÁVILA RODRIGUES, R.; SOUZA, L. P. Variabilidade espaço-temporal na mudança da paisagem no município de Acrelândia, AC. Enciclopédia Biosfera, Goiânia, v. 8, n. 14, p. 935946, 2012.

GASPARINI, K. A. C.; LYRA, G. B.; FRANCELINO, M. R.; DELGADO, R. C.; OLIVEIRA JUNIOR, J. F.; FACCO, A. G. Técnicas de Geoprocessamento e Sensoriamento Remoto Aplicadas na Identificação de Conflitos do Uso da Terra em Seropédica-RJ. Floresta e Ambiente, Seropédica, v. 20, n. 3, p. 296-306, 2013. http://dx.doi.org/10.4322/floram.2013.030

GOULART, A. C.; DELGADO, R. C.; OLIVEIRA-JÚNIOR, J. F.; GOIS, G.; SANTOS, E. O. Relação espectro-temporal entre índices de vegetação e a chuva na cidade do Rio de Janeiro. Revista de Ciências Agrárias/Amazonian Journal of Agricultural and Environmental Sciences, Belém, v. 58, n. 1, p. 277-283, 2015. http://dx.doi.org/10.4322/rca.1990

Intergovernmental Panel on Climate Change. Working Groups. < http://www.ipcc.ch/working_groups/working_groups.shtml >. Accessed on January, 2017.

IQBAL, M. An introduction to solar radiation. New York: Academic Press. 1983. 212p.

INPE - Instituto Nacional de Pesquisas Espaciais. Centro de Dados de Sensoriamento Remoto. $<$ http://www.dgi.inpe.br/CDSR/>. Accessed on April, 2019.

MARKHAM, B. L., BARKER, J. L. Thematic mapper band pass solar exoatmospherical irradiances. International Journal of Remote Sensing, v.8, p.517-523, 1987. https://doi.org/10.1080/01431168708948658

MMA, Ministério do Meio-Ambiente. Dados Unidades de Conservação. Accessed on: January 17, 2017 < http://www.mma.gov.br/areas-protegidas/unidades-de-conservacao>.

MOCOCHINSK, A. Y.; SCHEER, M. B. Campos de altitude na serra do mar paranaense: aspectos florísticos. Floresta, Curitiba, v. 38, n. 4, p. 625-640, 2008. http://dx.doi.org/10.5380/rf.v38i4.13158

MOLEDO, J. C.; ABIBE, C. H.; SAAD, A. R.; DALMAS, F. B. Impactos ambientais relativos à implantação do Rodoanel, trecho Norte, na bacia hidrográfica do tanque grande, município de Guarulhos, São Paulo.

Revista Geociências-UnG, Guarulhos, v. 14, n. 1, p. 49-70, 2015.

NUNES, M. T. O.; SOUSA, G. M.; TOMZHINSKI, G. W.; OLIVEIRA-JÚNIOR, J. F.; FERNANDES, M. C. Variáveis Condicionantes na Susceptibilidade de Queimadas e Incêndios no Parque Nacional do Itatiaia. Anuário do Instituto de Geociências (UFRJ. Impresso), Rio de Janeiro, v. 38, n. 1, p. 54-62, 2015.

RIBEIRO, E. P.; NÓBREGA, R. S.; MOTA FILHO, F. O.; MOREIRA, E. B. Estimativa dos índices de vegetação na detecção de mudanças ambientais na bacia hidrográfica do rio Pajeú. Geosul, Florianópolis, v. 31, n. 62 , p. 59-92, 2016. https://doi.org/10.5007/2177-5230.2016v31n62p59

ROUSE, J. W.; HAAS, R. H.; SCHELL, J. A.; DEERING, D. W. Monitoring vegetation systems in the Great Plains with ERTS. In 3rd ERTS Symposium, NASA SP-351 I, pp. 309-317, 1973.

SANTANA, M. F.; DELGADO, R. C.; JÚNIOR, J. F. O.; DE GOIS, G.; TEODORO, P. E. Variabilidade da Mata Atlântica baseado no índice EVI e variáveis climáticas em Cunha-SP, Brasil. Revista de Ciências Agroambientais, Alta Floresta, v. 14, n. 1, p. 37-44, 2016.

SILVA, E. R.; DELGADO, R. C.; DE SOUZA, L. P.; DA SILVA, I. S. Caracterização física em duas bacias hidrográficas do Alto Juruá, Acre. Revista Brasileira Engenharia Agrícola Ambiental, Campina Grande, v.18, n.7, p. 714-719, 2014. 
SOARES, T. S.; CÔRTES, M. A. S.; FREITAS, A. D.; CARLA, F.; VASCONCELOS, W. Avaliação dos impactos ambientais na área de influência direta do córrego da Estiva, município de Betim, MG, Brasil. Ciência e Natura, Santa Maria, v. 38, n. 2, p. 620-636, 2016.

XAVIER, A. C.; KING, C. W.; SCANLON, B. R. Daily gridded meteorological variables in Brazil (19802013). International Journal of Climatology, v. 36, p. 2644-2659, 2016. https://doi.org/10.1002/joc.4518 